\title{
Lessons from History, or the Perfidy of English Exceptionalism and the Significance of Historical France
}

\section{Citation}

Bates, Robert H. 1988. "Lessons from History, or the Perfidy of English Exceptionalism and the Significance of Historical France." World Pol. 40 (04) (July): 499-516.

\section{Published Version}

doi: $10.2307 / 2010316$

\section{Permanent link}

http://nrs.harvard.edu/urn-3:HUL.InstRepos:12211498

\section{Terms of Use}

This article was downloaded from Harvard University's DASH repository, and is made available under the terms and conditions applicable to Other Posted Material, as set forth at http:// nrs.harvard.edu/urn-3:HUL.InstRepos:dash.current.terms-of-use\#LAA

\section{Share Your Story}

The Harvard community has made this article openly available. Please share how this access benefits you. Submit a story.

Accessibility 


\title{
Review Articles
}

\section{LESSONS FROM HISTORY, OR THE PERFIDY OF} ENGLISH EXCEPTIONALISM AND THE SIGNIFICANCE OF HISTORICAL FRANCE

\author{
By ROBERT H. BATES*
}

T. H. Aston and C.H.E. Philpin, The Brenner Debate: Agrarian Class Structure and Economic Development in Pre-Industrial Europe (Cambridge: Cambridge University Press, 1987), 339 pp.

Steven L. Kaplan, Bread, Politics, and Political Economy in the Age of Louis XVI, 2 vols. (The Hague: Martin Nijhoff, 1976), 797 pp.

Steven L. Kaplan, Provisioning Paris: Merchants and Millers in the Grain and Flour Trade During the Eighteenth Century (Ithaca, NY: Cornell University Press, I984), 666 pp.

Hilton L. Root, Peasants and King in Burgundy: Agrarian Foundations of French Absolutism (Berkeley and Los Angeles: University of California Press, 1987), 277 pp.

Charles Tilly, The Contentious French: Four Centuries of Popular Struggle (Cambridge, MA: The Belknap Press of Harvard University Press, I986), $45^{6} \mathrm{pp}$.

\section{INTRODUCTION}

$\mathrm{T}$ HE field of development lacks a core body of deductive theory; it proceeds inductively instead. To account for development, scholars often draw lessons from history: they extrapolate from what is "known" to have happened in the past. As a consequence, the field belongs as much to historians as it does to social scientists.

In a field without theory, precedents assume the status of laws. In the development field, it is the historians who process the case materials from which law-like statements are drawn. Historians infer the lessons that become the new orthodoxies. Equally as important, they challenge old ones.

* I wish to acknowledge the impact of Philip Hoffman, Kathryn Norberg, Hilton Root, Robert Brenner, Douglas North, Roger Schofield, Eleanor Searle, Peter Lange, Michael Gillespie, John Aldrich, William Bianco, and Margaret Levi on my thinking. I hasten to add that none are responsible for the viewpoints in this article. 
For the development theorist, the implication is clear: keep a vigilant eye on the work of historians.

If specialists in the field were asked to appraise competing definitions of development, one of the most popular surely would be: development is the process by which town replaces country and industry replaces agriculture. Key works at theorizing in the development field focus on this transition.

In the contemporary literature, many scholars proceed cross-sectionally: the development field remains a branch of comparative politics, and scholars arrive at theories by contrasting behavior in present-day agrarian and industrial societies. But the grand theorists of development-Max Weber, Adam Smith, Karl Marx, and others-proceeded longitudinally. The theories they bequeathed the field evolved from studying how, in societies that had developed successfully, town had emerged from country, industry from agriculture, and mature capitalism from its agrarian antecedents.

This essay examines some recent works that focus on this transition. Recognizing that in this field history stands as parent to theory, we shall conduct a critical inquiry into several of the key lessons that have been drawn. We shall see that resistance to the market was not led by rural communities, but by the agents of capitalism; that peasants (particularly wealthy ones) often sought to champion private rights in property, whereas elites promoted collective ones; and that the historical shifting of the terms of trade against agriculture, which heralded the ascendancy of the commercial classes, has been deeply misunderstood.

Above all, I shall argue that, by focusing on the case of England, classical and Marxian theorists have based development studies on data that are profoundly misleading. Differing in critical respects both from its historical contemporaries and from the developing nations today, the English case supports invalid inferences. Rather, it is the French case from which the lessons of history should be drawn.

\section{Communal Resistance to the Rise of Capitalism}

Influential igth-century theorists held that pre-industrial societies were founded on principles that contrasted with those of market-based societies: in the words of Toennies, Gemeinschaft as opposed to Gesellschaft, or, in the words of Durkheim, "mechanical" as opposed to "organic" solidarity." Marx contrasted natural societies, where value was

' Ferdinand Toennies, Community and Society, trans. and ed. by Charles B. Loomis (East Lansing: Michigan State University Press, 1937); Emile Durkheim, The Division of Labor in Society (New York: Free Press, 1956). 
conferred by use, with market societies, where value was determined by exchange. ${ }^{2}$ The distinction also figures in the work of such influential non-Marxian theorists as Polanyi and Parsons. ${ }^{3}$

Contemporary scholars remain convinced that the principles which underlie agrarian societies contrast with the principles which govern market-based societies. Some have used this "lesson of history" to create a theory of political violence. Wolf, Migdal, and Scott, for example, have located the origin of agrarian rebellion in efforts to resist the impact of the market. ${ }^{4}$ The market, they hold, threatens the very foundations of rural community. It promotes self-interest and violates basic notions of human welfare in agrarian societies, such as the guarantee of subsistence. Thus, its spread is resisted by peasant communities.

These scholars maintain that, in part, the triumph of the market is assured by its possession of an active ally: the nation-state. In the contemporary period, for example, the spread of market forces has been promoted by imperialism. In the reigning orthodoxy of peasant studies, peasant rebellions thus become communalistic rebellions, representing forms of protest against the market. And while they are profoundly anticapitalist, they are clothed in the rhetoric of nationalism, as they also entail resistance against foreign political domination.

In The Contentious French, Charles Tilly-a historian and sociologist who has made well-known contributions to the development field5- perpetuates important strands of the contemporary orthodoxy. But, by lovingly exploring a rich tableau of historical data, he opens the door to revisionists. For the lessons that he reaffirms appear to be contested by the facts that he uncovers.

Tilly's mission, he states, is to address the question, "How did the development of capitalism and the concentration of power in the national state affect the ways that ordinary people contended-or failed to contend-for their interests?" (p. 5). His answer is that the intrusion of capitalism and the nation-state led to protests in early modern France that represented the reassertion of community. This lesson, he argues, is most

${ }^{2}$ Karl Marx, Capital (New York: Clark A. Kerr, I9o6), and esp. Grundrisse [Outlines] (Harmondsworth, England: Penguin Books, 1973).

3 Karl Polanyi, The Great Transformation (Boston: Beacon Press, 1957); Talcott Parsons, The Social System (New York: Free Press, 1964).

${ }_{4}$ Eric R. Wolf, Peasant Wars of the Twentieth Century (New York: Harper Torchbooks, 1969); James C. Scott, The Moral Economy of the Peasant: Peasant Rebellion and Subsistence in Southeast Asia (New Haven and London: Yale University Press, 1973); Joel S. Migdal, Peasants, Politics, and Revolution (Princeton: Princeton University Press, I974). For more recent works, see Eric R. Wolf, Europe and the People Without History (Berkeley and Los Angeles: University of California Press, 1982), and James C. Scott, Weapons of the Weak: Everyday Forms of Peasant Resistance (New Haven and London: Yale University Press, 1985).

5 See, for example, Charles Tilly, ed., The Formation of National States in Western Europe (Princeton: Princeton University Press, 1975). 
vividly conveyed by a characteristic form of political protest, the grain riot: "Blockage of grain expressed the demand of ordinary people that the needs of the community take priority over the requirements of the market" (pp. 2I-22).

As Tilly's own work - and the work of others-has confirmed, political demands for subsistence were indeed characteristic of European society in the early modern period. Local communities faced with shortages of food and rising prices used political power to prevent the shipment of the grain that could meet their needs for subsistence. ${ }^{6}$

The key questions, however, are: Did these protests represent revolts against the market? Did they represent revolts against the market's putative ally, the state? In short, did they represent a revolt by precapitalist political communities?

For the conventional interpretation to hold, two things must be true. One is that those who entered the rural community to procure grain must have been agents of the market. The other is that the state officials who backed them must be champions of the market.

Tilly's data, and the data of others, show that it was often the levies of the armed forces that precipitated the grain riots; the military had little incentive to pay high prices for food (Tilly, 83ff.). ${ }^{7}$ Other levies were made to provision Paris. Like Tilly, Robert Brenner ("Agrarian Class Structure and Economic Development in Pre-Industrial Europe," chap. I, pp. 10-63, in Aston and Philpin) relates that the French monarchy frequently mounted wars against the regional nobility. Its power base usually rested narrowly on Paris. The bureaucracy, the armed forces, and the aristocracy also were concentrated in Paris. And the residents of Paris demanded cheap food.

Kaplan ( 1976 ) recounts that, in order to feed Paris, the government developed an elaborate bureaucracy for securing food from the countryside. ${ }^{8}$ Its purpose was not only to feed Paris, but to do so at low pricesin other words, to counter market forces. It sought to purchase the grain at prices cheaper than those offered by consumers living in regional markets—or abroad.

${ }^{6}$ See, for example, the materials in Tilly (fn. 5); Louise A. Tilly, "The Food Riot as a Form of Political Conflict in France," Journal of Interdisciplinary History 2 (1971), 23-57, and J. Stevenson, "Food Riots in England, I 792-1 818" in R. Quinault and J. Stevenson, eds., Popular Protest and Public Order: Six Studies in British History (London: George Allen \& Unwin, 1974). Critical to the interpretation of these riots is Edward P. Thompson, "The Moral Economy of the English Crowd in the Eighteenth Century," Past and Present 52 (1971), 76-1 36, and George Rude, "La taxation populaire de mai 1775 à Paris et dans la region Parisienne" [The common taxation of May 1775 in Paris and in the Paris region], Annales Historiques de la Revolution Française 28 (1956), I39-79.

7 See also the materials in Louise Tilly (fn. 6), and Stevenson (fn. 6).

${ }^{8}$ For the correlation between unrest and the price of food, see George Rude, Paris and London in the Eighteenth Century (London: Collins, 1970). 
The image that Tilly conveys is that of the state actively promoting the formation of markets and thereby provoking communal unrest in the agrarian hinterland. In keeping with the orthodox strain of contemporary peasant studies, he therefore interprets grain riots as a form of communal protest against the rise of capitalism, with the latter being championed by the market and the state. But the principal demanders of food were not agencies of the market; they were agencies of the state-the military or the bureaucracy who sought to override the operations of the market, rather than to promote them. They wanted food at cheaper prices than the unregulated market would provide.

The composition of the groups who resisted the export of grain constitutes a further challenge to the orthodox view. Tilly's language, and that of his colleagues in the field of peasant studies, suggests that it was agrarian communities who resisted the intrusion of the market and thus, implicitly, the rise of capitalism. But neither logic nor evidence bears out such an interpretation. Rather, both suggest that the enemies of the grain trade would be the creatures of capitalism-the nascent bourgeoisie and the proletariat-rather than the relics of the pre-capitalist past, the agrarian producers. 9

Logic suggests that the consumers rather than the producers would resist the export of grain, for exports would lead to a rise in local prices. Although in times of drought or crop failure, the grain producers themselves became net consumers and then had reason to resist food exports, most often they were suppliers. If they could obtain higher prices by exporting grain from the local community, they would presumably favor grain exports.

It is relevant, therefore, that historians have found that food riots took place long after the end of subsistence crises in both England and France. ${ }^{10}$ Moreover, these riots were led by consumers, not producers: members of the new urban populations that had grown up in the regional centers of England and France. Thus, Stevenson writes that food riots in England tended to take place in towns, communication centers, and ports. They usually occurred in areas of mining and quarrying; in areas where workers and builders were constructing canals, dykes, and roads;

${ }_{9}$ The picture is further complicated by the fact that members of the aristocracy who lived in Paris also owned land in the grain-growing areas. In their capacity as local elites, they often ruled against the right of grain "exports" to Paris and in favor of the paramountcy of local markets. The political interests of the aristocracy thus conflicted with their economic interests in shipping grain to high-priced markets; and their interests as producers, which were enhanced by high prices, conflicted with their interests as urban consumers, which were enhanced by low prices. These complexities should make the analyst suspicious of any simplistic rendering of the class interests of the aristocracy.

${ }^{10}$ For France, see Louise Tilly (fn. 6), 25. Stevenson too stresses that food riots occurred even after subsistence crises had ended in England (fn. 6, pp. 4 off.). 
and among the rural workers. Louise Tilly finds that in 18 th-century Burgundy, "within the province, which was quickly tapped by the large military and urban consumers, smaller cities sought food and the countryside armed to prevent loss of vital supplies. 'There was open war with the peasants to get their grain,' wrote a canon of Beaune."

Too often, the lesson that is drawn seems to indicate that rural, agrarian interests fight against the penetration of the market, particularly when the market threatens basic food supplies and creates crises of subsistence. Historically, there have indeed been political struggles over food supplies. But those who imperiled local subsistence most often were not agents of the market; rather, they were agents of interests that sought to override market forces. Often, those who resisted the export of food supplies were not the members of the agrarian community; the resistance tended to come from the local consumers rather than the producers of food. ${ }^{12}$ And food riots continued even after subsistence crises subsided.

The agents of the new capitalism-the workers, artisans, burghers, as well as those who governed them-cloaked their demands for cheap food in the myth of the precapitalist community. Kaplan shows that agrarian interests - the producers of grain-trumpeted the virtues of "liberty and the market" and called for the end of irrational "feudal fetters" on the market's operations (Kaplan, I976, I, pp. I I 4 ff.). Clearly, key lessons of history must be unlearned.

\section{Peasants as Communitarians}

Another so-called lesson of history is that, with the transition from an agrarian to an industrial society, peasants tend to experience a loss in welfare. It is held that capitalism promotes the formation of private rights in property; and that, with the privatization of common rights, poor people lose their institutional defenses against the risks of the market. For this reason too, the rural poor are said to rebel and resist the rise of capitalism.

This interpretation has been put forward for peasant rebellions in France. ${ }^{13}$ It has been applied to the study of rural violence in England,

"Louise Tilly (fn. 6), 52.

${ }^{12}$ As noted above, members of the agrarian community would on occasion be net purchasers of food, and therefore would resist higher prices for it. This was particularly true of cottagers and farm laborers, who at times of subsistence crises faced both a lowering of the wage rate and higher food prices; they would therefore be particularly motivated to resist the "exportation" of food. For a brilliant analysis, see Amartya Sen, Poverty and Famines: An Essay on Entitlement and Deprivation (Oxford: Clarendon Press, $198 \mathrm{I}$ ).

${ }_{13}$ Marc Bloch, French Rural History, trans. by Janet Sondheimer (Berkeley and Los Angeles: University of California Press, 1970); Emmanuel Le Roy Ladurie, Histoire de la France Rurale [History of rural France], ed. by Georges Duby and Armand Wallon, 4 vols. (Paris: Seuil, I976); Albert Soboul, "Problèmes paysannes de la communauté rurale (xviiie-xixe)" 
especially at the time of the Parliamentary enclosures. ${ }^{14}$ And, as a "lesson of history," it has been applied to the study of peasant rebellions in the modern world. ${ }^{15}$

Again, Tilly perpetuates this orthodoxy. He argues that:

The second common form of anti-capitalist action was ... local resistance to landlords' consolidation of lands and of rights in the land (p. 23).

Popular opposition did not aim specifically at the landed nobility. It aimed at the landlords of any order who chewed up the rural community's collective rights (p. 24).

But who actually promoted the preservation of collective rights? In some cases, to be sure, it was the peasants. But the more we learn, the more we come to realize that the defenders of common rights were often drawn from the ranks of others.

Some came from the elites who dominated village institutions and thereby captured the benefits of common property. ${ }^{16}$ Important work by Philip Hoffman shows that, in Northern and Eastern France, herders constituted the primary opponents of private enclosure. Landlords, wealthy peasants, and local seigneurs usually owned these herds. They also tended to hold the right to stint on common lands, and to exercise it because they feared the loss of grazing privileges. ${ }^{17}$ Kathryn Norberg argues in a study of a village in southwestern France:

The commons ... profited mainly the elite who jealously guarded its benefits.... they were the principal beneficiaries of most traditional practices, be they open fields or communal woods. No wonder then that they were among traditions' strongest defenders. ... historians have mistaken the elite's views for those of the whole community. ${ }^{18}$

[Peasant problems of the rural community, I8th-igth century], in Problèmes paysannes de la Revolution 1778-1848 (Paris: Maspero, 1975).

${ }_{14}$ J. L. and Barbara Hammond, The Village Laborer $1760-1832$ (New York: Harper Torchbooks, 1970); Edward P. Thompson, The Making of the English Working Class (New York: Vintage Books, 1962).

${ }^{15}$ See, for example, Scott (fn. 4, 1974).

${ }^{16}$ This line of historical interpretation was provided by Alfred Cobban in The Social History of the French Revolution (Cambridge: Cambridge University Press, 1968). In addition to the recent work of Norberg and Hoffman (fns. I7, I8, and I9), see Root's discussion in Peasants and King, pp. 16, 95-97, $125,153 \mathrm{ff}$, and $216-17$.

${ }^{17}$ Philip T. Hoffman, "Institutions and Agriculture in Old-Regime France," paper prepared for the Caltech-All University of California Group in Economic History Conference on Pre-Industrial Developments in Peasant Economies (Huntington Library, Pasadena, CA), May 22-24, 1987.

${ }^{18}$ Kathryn Norberg, "The Struggle Over the Commons: Antiseigneurialism and Social Tension in the Peasant Community," pp. 26-27. The work of Hoffman (fn. I 7 ) and Norberg (fns. 18 and $\mathrm{I}$ ) is to be featured in a special edition of the journal Politics and Society, edited by Margaret Levi and Robert H. Bates. Also see Samuel L. Popkin, The Rational Peasant (Berkeley and Los Angeles: University of California Press, 1979), which makes a comparable argument based on data from contemporary Vietnam. 
In France, the local elites had an important ally: the central administrators. Under a law passed in 1439 , the monarchy could tax the peasantry directly and without convoking the Estates General. Locked in combat with the nobility and distrustful of other elites, the king was afraid to negotiate for revenues with privileged orders. Instead, he sought to secure his tax base by preventing encroachments upon peasant property. This ability to tap the streams of income generated by the peasant communities played another critical role in the state's finances: it underwrote the monarch's capacity to repay-and thus to attract-foreign loans. This argument forms the central thesis of Hilton Root's Peasants and King in Burgundy. Root draws the important implication:

Communal rights and properties and collective responsibility for tax collection were not spontaneous expressions of peasant culture. Both were measures imposed from above to ensure political dominance of the agrarian population and to facilitate resource extraction (pp. 232-33).

Perhaps we have gone too far. What, after all, do we know of the preferences of the peasants? Do we have any insight into what they themselves would have preferred? We do, at least to a modest degree. Norberg has gained access to the response of $43 \mathrm{I}$ peasant communities to a law passed after the French Revolution, which allowed peasants to divide common land into private holdings. She concludes that, when given the chance to break up the commons, peasant villages elected to do so. ${ }^{19}$ In response to an investigation of the implementation of this law, the government learned that even prior to the new policy, 240 villages had decided to divide up the commons; i 8 voted to partition; and only 46 had declined to do so. ${ }^{20}$ Most of the villages that elected not to divide did so because their commons were too wet, too dry, or too hilly to cultivate. Norberg concludes, "If the commons had not been encroached upon, they were, most likely, virtually worthless and therefore not worth partitioning. Here lay, it appears, the main reason peasants chose to leave the commons as collective property."

Too often, people in the development field seem to have drawn the lesson that local communities struggle against the privatization of interests brought on by capitalism, and do so in order to safeguard the interests of the poor. Instead, there is ample historical evidence to suggest that collective property is championed by elites and that it affords a way of privatiz-

19 Kathryn Norberg, "Dividing up the Commons: The Political Economy of EighteenthCentury French Agriculture," paper prepared for the Caltech-All University of California Conference (fn. 17 ).

${ }_{20}$ Twenty-seven had no knowledge of the law.

${ }^{21}$ Norberg (fn. 19), 7 . 
ing the benefits to be extracted from agrarian society while spreading the costs widely among its members. It appears that champions of collective property possess private interests themselves, and use the corporate interests of the rural community to legitimate their claims. ${ }^{22}$

\section{Peasant Farming as a Retardant to Development}

Anyone who works in present-day developing areas knows that, despite overwhelming evidence to the contrary, significant elites and especially intellectuals remain convinced that peasant farming provides an inadequate foundation for development. In post-independence Africa, for example, the governments of Somalia, Ethiopia, Mozambique, Zambia, Tanzania, and Ghana have invested heavily in state farms; alternatively, through "villagization" or other means, they have sought to promote large-scale farming. ${ }^{23}$ In the pre-independence period, the governments of Kenya and Rhodesia determined, as a matter of policy, not to rely on the output of peasant farmers. It was held that, in view of their commitment to subsistence, peasant farmers produced a highly variable level of marketable surplus, thus imposing risks upon consumers and the state. ${ }^{24}$ Policy makers therefore chose to rely instead upon the large-scale farmers who, they believed, produced a more reliable flow of marketable output.

The superiority of the large-scale farmer is a lesson of history drawn chiefly, it would appear, from commentaries on the 18 th-century rivalry between the superpowers of that era: England and France. Influential observers attributed England's military superiority in large part to her economic prosperity; her superior wealth, in turn, was thought to be due to the greater productivity of her agriculture; and the last was believed to be based on the greater technical and economic efficiency of England's large-scale farmers. ${ }^{25}$ The retarded state of the French economy was as-

${ }^{22}$ Also see the discussion in Robert H. Bates, "Some Conventional Orthodoxies in the Study of Agrarian Change," World Politics 36 (January 1984), 234-54. This is not to deny that there were cases where the poor depended upon common rights, for pasture, for forest products, or for gleaning, and where they allied themselves with those who resisted the break-up of common lands. In general, however, it appears to have been the local elites who dominated the commons.

${ }^{23}$ See, for example, the discussion in Robert H. Bates, Markets and States in Tropical Africa (Berkeley and Los Angeles: University of California Press, 1981).

${ }^{24}$ See the discussion and review of this debate in William O. Jones, Marketing Stable Food Crops in Tropical Africa (Ithaca, NY: Cornell University Press, 1972). William Allan, The African Husbandman (New York: Barnes \& Noble, 1965) remains the classic argument of this position.

${ }_{25}$ The intellectual background is brilliantly presented in Kaplan (1976). See also the thoughtful review in Michael Lipton, Why Poor People Stay Poor: Urban Bias in World Development (Cambridge: Harvard University Press, 1977). 
cribed to France's lagging rural sector, where productivity remained low, technical progress insufficient, and farm size diminutive. England had seized the capitalist road to development; France remained backward, mired in peasant production.

This analysis was championed in a series of influential works by Arthur Young, published in the 18 th century. ${ }^{26}$ It was endorsed by the leading economists of the time, ${ }^{27}$ and exercised a powerful influence upon policy makers-especially in France, where the government sought to reform its rural economy the better to finance its military ventures. ${ }^{28} \mathrm{Karl}$ Marx helped to inject this analysis into contemporary development studies. While condemning the stagnation of peasant production, ${ }^{29}$ Marx attributed the initial surge toward industrialization to the rise of capitalist farming. $3^{\circ}$

This lesson of history-that peasant production is inefficient and incapable of generating an agricultural surplus adequate for the promotion of development - continues to influence the writings of contemporary historians. Among the works reviewed here, its power is perhaps most strikingly underscored by Brenner's compelling re-analysis of the decline of feudal society. The triumph of modern capitalism, he argues, was marked by the rise of commercial farming: large, capital-intensive farms, employing wage labor. States in which development was retarded were marked instead by the capacity of the bureaucracy and others to ally with an organized peasantry and to block the rise of commercially minded agrarian classes:

In England we find the landlords consolidating holdings and leasing them out to large capitalist tenants who would in turn farm them on the basis of wage labor and agricultural improvement. But in France we find comparatively little consolidation. Even the land controlled directly by the landlords - that is by demesnes farmed out on terminable contract leases-was

\footnotetext{
${ }^{26}$ See Arthur Young, Six Weeks Tour Through the Southern Counties of England and Wales (London: W. Strahan, I 768); A Six Months Tour Through the North of England, and ed. (London: W. Strahan, I771); and A Farmer's Tour Through the East of England (London: W. Strahan, I77I).

${ }^{27}$ See Ronald L. Meek, The Economics of Physiocracy (Cambridge: Harvard University Press, 1963).

${ }^{28}$ Kaplan's work, esp. 1976, provides valuable insights into the influence of economic technocrats upon policy making in I 8 th-century France. Also see Alexis de Tocqueville, The Old Regime and the French Revolution, trans. by Stuart Gilbert (New York: Anchor Books, 1955).

${ }^{29}$ See the materials gathered in Norire Ter-Akopyan, ed., Marx, Engels: Pre-Capitalist Socio-economic Formations (London: Lawrence \& Wishart, I979).

$3^{3}$ Marx, Capital (fn. 2), part VIII. Subsequent Marxian theorists attributed the relative stagnation of Eastern and Central Europe to the prevalence of peasant agriculture; they located in large-scale farming the motor force for the rise of capitalism. A useful review is contained in David Mitrany, Marx Against the Peasant (New York: Collier Books, 196r). See also V. I. Lenin, The Development of Capitalism in Russia (Moscow: Progress Publishers, 1956).
} 
generally let in small parcels and cultivated by small peasant tenants. At the same time, of course, fragmentation dominated the sector of peasant proprietorship. These different class structures determined substantially different results in terms of agricultural productivity and, indeed, wholly disparate overall patterns of economic development (Brenner in Aston and Philpin, 46).

Students of contemporary agriculture, particularly in Asia-Schultz, Hayami, Ruttan, Sen and others-have largely discredited this "lesson of history." ${ }^{11}$ More important for this essay, the thesis is strongly disputed by contemporary historians of agricultural development in Europe. As phrased most dramatically by Goldstone, "There is a persistent belief ... that much of the magic in English farming was due to its 'larger' farms, with their land lord/capitalist tenant/wage laborer, compared with the proliferation of tiny plots in France. This is, to be polite, poppycock." ${ }^{2}$

As the work of Robert C. Allen and others has shown, there was a steady growth of productivity on all British farms, be they enclosed or open-field, large or small, from the time of the middle ages through the I 8th century; 33 because of the dominance of open-field farming throughout much of this period, ${ }^{34}$ enclosed, large-scale farmers contributed relatively little to the differences in productivity that distinguished British from French agriculture. 35 According to Allen,

Corn yields in the English midlands approximately doubled between the middle ages and the nineteenth century. Wheat, for instance, which had yielded about ten bushels per acre in the fifteenth century, provided about 20-22 bushels c. I80o. Compared to that increase, the difference between open and enclosed yields at the end of the eighteenth century was small, i.e. open field farmers (like enclosed farmers) had accomplished almost all of the advance. $3^{6}$

${ }^{31}$ Theodore W. Schultz, Transforming Traditional Agriculture (New Haven and London: Yale University Press, I964); Yujiro Hayami and Vernon W. Ruttan, Agricultural Development: An International Perspective (Baltimore and London: The Johns Hopkins University Press, 1971); Amartya K. Sen, "Size of Holding and Productivity," The Economic Weekly I6 (1964), 323-26.

${ }^{32}$ Jack Goldstone, "Regional Ecology and Agrarian Change in England and France, I500I 7oo," paper presented at the Caltech-All University of California Conference (fn. I7), 24. A revised version of this paper is scheduled to appear in a special edition of Politics and Society (see fn. I 8).

${ }_{33}$ Allen, "Enclosure and Productivity Growth, I 459-1 850," typescript (Department of Economics, University of British Columbia, 1984). Allen's data remain controversial.

${ }^{34}$ For data on the rate of enclosure, see J. R. Wordie, "The Chronology of English Enclosure 1500-1914," Economic History Review 36 (November 1983), 483-505.

35 For data on these differences, see Anthony Wrigley, "Urban Growth and Agricultural Change: England and the Continent in the Early Modern Period," Journal of Interdisciplinary History 15 (1985), 716-21.

${ }^{36}$ Robert C. Allen, "Enclosure, Farming Methods, and the Growth of Productivity in the South Midlands," Discussion Paper No. 86-44 (rev.) (Department of Economics, University of British Columbia, January 1987), I6. See also J. A. Yelling, Common Field and Enclosure in 
To what, then, is the greater English productivity to be attributed? Allen suggests biological improvements: seed selection and the use of improved plant species. Others suggest the growth of the market. In England, to a much greater degree than in France, a national market had formed. Some areas produced wool for export. Areas immediately adjacent to towns specialized in truck farming and the production of perishables. ${ }^{37}$ Farms near the coast produced meat and grains, which they then shipped by water to urban centers. And those who worked the heavier soils of the interior shifted out of arable production into the production of livestock. Studies of subsistence crises also suggest the relatively greater integration of the English market; Appleby and others indicate that there was a far greater mobility of grain between regions of abundant harvests and those of dearth in England than there was in France, and thus a greater capacity to blunt the consequences of food shortages..$^{38}$

Major investigations of present-day agriculture refute the position that peasant agriculture retards development. So do important reassessments of the historical data.

\section{The Squeeze on Agriculture}

Viewed in historical perspective, development is a process of structural change. It results from the movement of resources-land, labor, and capital-out of agriculture and into other sectors, such as industry, where these resources can be used more productively. In summary notation:

$$
\frac{d G N P}{d t}>0 \quad \longrightarrow \quad \frac{d A g \cdot / G N P}{d t}<0,
$$

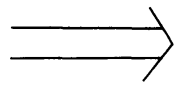

where $d$ stands for change, $t$ for time, GNP for gross national product, and $A g . / G N P$ for agriculture as a portion of the gross national product.

One way in which this shift of resources takes place is through productivity increases in agriculture. Technical change in agriculture leads to increased supplies of agricultural products; because the demand for

England 1450-1850 (Hamden, CT: Archon Books, 1977), and M. Turner, "Agricultural Productivity in England in the Eighteenth Century: Evidence from Crop Yields," Economic History Review, 2nd series, 35 (1982), 489-5 10.

${ }_{37}$ See Marjorie Mackintosh, "Economic Change in Southeast England, I350-160o," paper presented at the Caltech-All University of California Conference (fn. I7).

${ }^{38}$ See Andrew Appleby, "Grain Prices and Subsistence Crises in England and France, 1590-1 740," Journal of Economic History 39 (December 1979), 865-87; E. A. Wrigley and Roger Schofield, The Population History of England 1541-1871 (Cambridge: Harvard University Press, 1981); David Weir, "Markets and Mortality in France," I600-1 789," manuscript, n.p., n.d.; Joan Thirsk, ed., Agrarian History of England and Wales (Cambridge: Cambridge University Press, 1984). 
such products is inelastic, prices fall, and the resources of land, labor, and capital employed by marginal producers fail to earn revenues equivalent to their opportunity costs, and so seek productive employment elsewhere. Through the Mills-Marshall treadmill, dynamic transformations in agriculture lead to the structural transformation of the greater economy. ${ }^{39}$

Structural transformation can also be achieved by policy-induced shifts in relative prices. Here, another lesson of history is brought to bear: that industrialization was achieved by shifting the terms of trade against agriculture..$^{\circ}$

Central to this inference is the history of the Corn Laws, and in particular their repeal. Classical economists, especially Ricardo, had attacked the Corn Laws and stressed the way in which they privileged the interests of the landed classes. Manufacturers and workers had combined in demanding their repeal; according to Marshall, "the Victory of the AntiCorn Law League signalized the extension of the interests of industrial capitalists and of ... their rule over England." ${ }^{41}$ From the history of the Corn Laws, many therefore concluded that the shift from an agrarian to an industrial society could be achieved by altering the terms of trade between town and country. ${ }^{42}$

This way of promoting industrialization strongly appealed to ambitious elites. In the Soviet Union, for example, some, like Bukharin, favored offering positive incentives to farmers; their response in terms of increased supply would then induce the dynamic adjustments leading to the release of resources to industry. Others, like Preobrazhensky, distrusted the willingness and ability of peasants to respond to price incentives; citing the lessons from the history of industrialization in Britain, they felt that forceful state intervention to shift the terms of trade against

${ }^{39}$ See the excellent discussion in Alain de Janvry, The Agrarian Question and Reformism in Latin America (Baltimore: The Johns Hopkins University Press, $198 \mathrm{I}$ ). The central issue of whether industrialization resulted from the transfer of resources from agriculture is addressed in François Crouzet, Capital Formation in the Industrial Revolution (London: Methuen, 1972), and Roderick Flood and Donald McClosky, eds., The Economic History of Britain since I70o, I (Cambridge: Cambridge University Press, 1981).

$4^{\circ}$ The history of these ideas is ably reviewed in Lipton (fn. 25). See also E. Preobrazhensky, The New Economics, trans. by Brian Pearce (Oxford: Clarendon Press, 1966); Alexander Erlich, The Soviet Industrialization Debates, 1924-1928 (Cambridge: Harvard University Press, ig6o).

${ }^{41}$ Leon S. Marshall, "The Emergence of the First Industrial City: Manchester I 780-1850," in Caroline F. Ware, ed., The Cultural Approach to History (New York: Columbia University Press, I940), I58. A sophisticated treatment is provided by Timothy J. McKeown in "The Politics of Corn Law Repeal Reconsidered," paper presented at the Annual Meeting of the American Political Science Association, Chicago, September 3-6, 1987. In this paper, McKeown reanalyzes the famous Aydelotte data set. See William Aydelotte, "The Country Gentlemen and the Repeal of the Corn Laws," English Historical Review 82 (1967), 47-6o.

${ }^{42}$ See in particular Ashok Mitra, Terms of Trade and Class Relations: An Essay in Political Economy (London: Frank Cass, 1977). 
agriculture represented the best policy. The advocates of political intervention won out; by shifting the structure of relative prices against rural producers, they taxed the rural sector in favor of industry. ${ }^{43}$ This policy was subsequently followed by others. 44

Although it is now widely recognized that turning the terms of trade against agriculture is far more likely to lead to stagnation than to growth, this lesson of history was used for decades to advocate and to justify the imposition of negative pricing policies on farmers.

Because reasoning from precedent will remain an important guide to policy in the development field, we are motivated to reassess the historical record. When we do so, we learn three new lessons. The first is that the repeal of the Corn Laws represented the repeal of a subsidy rather than the imposition of a tax; structural transformation had thus been achieved where agriculture was subsidized rather than squeezed. The second is that the development field has drawn historical lessons from a highly anomalous case; it therefore rests upon unfirm data. The third is the centrality of politics to the economics of development.

\section{Lesson ONE}

When re-assessing the historical precedents that proved to be misleading guides to policy, one quickly recognizes that the repeal of the Corn Laws did not represent the imposition of a tax on agriculture. The policy of the British government can be summarized as choosing that price for farm products which represents the

$$
\max \left(P_{d}, P_{w}\right)
$$

where $P_{d}$ is the price on the domestic market and $P_{w}$ the price on the world market. Under the terms of the Corn Laws, when the world price was higher than the domestic price, farmers could export grain; when it was lower than the domestic price, imports were prohibited. The policy thus represented a high-price policy, which favored farmers at the expense of consumer interests.

It is ironic that, rather than justifying the policy prescription of shifting the terms of trade against farming, the English case justifies the opposite. The structural transformation of English agriculture took place in the context of policies that protected high agricultural prices.

${ }^{43}$ See Erlich (fn. 40), as well as Maurice Dobb, Soviet Economic Development Since 1917 (New York: International Publishers, 1948).

${ }^{44}$ See the discussion in Theodore W. Schultz, ed., Distortions of Agricultural Incentives (Bloomington: Indiana University Press, 1978). 


\section{Lesson Two}

As Heckscher and others point out, England's commitment to policies favoring farmers made that nation unique in its time. A key element of "mercantilist policies," Heckscher suggests, was "provisioning": supplying cheap grain to urban centers. Other governments intervened to defend low domestic prices by banning the export of grain when world prices were higher than the domestic price, and by allowing the import of grain when domestic prices were high. They acted, in other words, to implement policies which selected the

$$
\min \left(P_{d}, P_{w}\right) .45
$$

The policies everywhere else in Europe were exactly the opposite of those followed in England.

It is important to stress the level of English exceptionalism. Economists, Marxist and otherwise, have long taken the English case as prototypical of early industrialization. Many of the lessons inferred about the origins of successful capitalist development derive from this case. And yet, as we have seen, England proves to have been anomalous.

French policies toward agriculture were more characteristic of those of her historical contemporaries; they were also more typical of those that characterize the developing nations today. French agriculture was peasant-based; productivity was relatively low; the government adhered to a low-price policy; and it maintained a bureaucracy to secure cheap grain to feed its civil servants, its armed forces, and its capital city. The French case-not the English, with its large farms, subsidized rural sector, and relatively free internal trade-better approximates the world of the contemporary developing nations. Thus, it follows that too much theorizing about development has been based on the case of England, and too little on that of France.

Development specialists would do well to put aside their Marx, Smith, Ricardo, and Mill and instead consult the writings on France, such as those produced by Tilly, Brenner, Root, and Kaplan.

\section{Lesson Three}

The third lesson leads to a renewed respect for the centrality of politics to the economics of development.

England, like every other developing country, originally intervened in agricultural markets in an effort to defend consumer interests. Gras,

${ }^{45}$ Eli F. Heckscher, Merchantilism, II (London: George Allen \& Unwin, I93I), 8off. 
Ponko, Outhwaite, and others have examined the process by which the government sought to regulate the grain trade so as to preserve low prices..$^{6}$ The frequency of such interventions declined in the 17 th century, however, and policy was reversed in I688, with the adoption of the Corn Laws. ${ }^{47}$ As Kaplan, Tilly, and others show, the government in France, by contrast, continued to intervene in grain markets in order to preserve lower, not higher, grain prices.

One reason for the disparate behavior of the two governments may have been the relative security of food supplies. The data suggest that, by the 17 th century, food shortages were less frequent in England than in France; there were fewer subsistence crises. Just as government policy affected the performance of the agrarian economy, so the performance of the economy may have affected the incentives for governments to assure the supply of low-cost food..$^{8}$ There is a strong case to be made for the significance of this reciprocal causation.

The books reviewed in this essay also suggest, however, that there may have been important political reasons for the contrast in public policies. Root, Brenner, Tilly, and Kaplan argue that agricultural policy in France was driven in part by the need for revenues to finance foreign wars and in part by the need to achieve internal security. The English monarchy, too, needed money for its foreign wars; but, in the i 7 th century, the domestic threat to it came not so much from the capital city as from parliament.

Viewed from this vantage point, the date of the Corn Laws- the hallmark of English exceptionalism-is instructive. The laws were passed in I688 as part of the terms negotiated between parliament and the king who had been chosen by parliament: William of Orange.49 Parliament had overthrown the monarchy; it had ruled England for decades; and by turning to William and Mary, it had imported a new royal family. The landowners who dominated parliament sought the commitment of the monarch to policies that would raise the price of grain; the monarch

${ }^{46}$ N.S.B. Gras, The Evolution of the English Corn Market (Cambridge: Cambridge University Press, 1915); V. Ponko, "N.S.B. Gras and Elizabethan Corn Policy: A Re-examination of the Problem," Economic History Review, 2nd series, I7 (1964), 24-42; R. B. Outhwaite, "Dearth and Government Intervention in English Grain Markets, I590-I 700," Economic History Review, 2nd series, 34 (198I), 380-406, and "Food Crises in Early Modern England: Patterns of Public Response," in Proceedings of the Seventeenth International History Conference, ed. Michael Flinn (Edinburgh: The University Press, 1978).

${ }^{47}$ See the discussion in Adam Smith, The Wealth of Nations (Chicago: University of Chicago Press, I976), Book I, pp. 2 I gff.

${ }_{48}^{8}$ See, for example, Weir (fn. $3^{8}$ ); the contributions in Robert I. Rotberg and Theodore K. Rabb, Hunger and History (Cambridge: Cambridge University Press, 1985); and Appleby (fn. 38).

${ }^{49}$ See Smith (fn. 47), Book I, pp. 21 gff. 
sought higher taxes. The result was a political compromise. The king exchanged protection of the economic interests of grain producers for parliament's agreement to a land tax. The landed elites and the monarch adopted a program of agrarian protection and split the economic benefits between them.

Why, then, did not London rebel, as Paris did? $5^{\circ}$ Brenner's new research shows that the governing elites in London differed significantly from those in Paris. ${ }^{51}$ London was a port city, and its government was dominated not by civil servants and lawyers, but by merchants and traders. The elites of Paris were consumers of grain; those of London were traders. Unlike their Parisian counterparts, those who dominated the government of London could benefit from the exportation of grain; free trade in grain therefore was less of a threat to the powerful in the capital city.

Kaplan's study of the politics of agricultural policy in France demonstrates that the coastal cities joined the landed classes in demanding the liberalization of the grain trade. London was a coastal city. Had the capital of France been Marseille rather than Paris, the monarchy of France in the 18 th century might well have shifted to market principles in the making of agricultural policy.

\section{Conclusion}

In this essay, we have examined five recent works that cast light upon the foundations of the development field. To a great extent, those foundations are based on lessons of history that have not been properly interpreted.

Several of the central theses about the transition from agrarianism rest on debatable grounds. For example, the nation-state did not champion the extension of competitive markets; rather, public officials sought to limit and regulate them. It was the workers and burghers - the new classes that emerged with capitalism-who used the language of community to resist the market; often, it was agricultural producers who preferred unfettered trade. Peasants often sought to break up commons; elites often sought to preserve them. Small-scale farmers accounted for much of the productivity gains in the period preceding the Industrial Revolution; peasant agriculture was not stagnant. Moreover, deep mis-

${ }^{5}$ As Rude has shown, the rebellions by the London mob correlated with the price of bread. See Rude (fn. 8).

${ }^{5}$ Robert Brenner, forthcoming. 
understandings surround the history of the terms of trade and the role they played in "the great transformation."

Among the most significant of the new lessons learned, however, is the intellectual tyranny of the English case-and the significance of that of France. 